\title{
INTEGRATION OF ENTREPRENEURSHIP INTO HIGHER EDUCATION (EDUCATIONAL SCIENCES) IN LITHUANIA AND LATVIA: FOCUS ON STUDENTS' ENTREPRENEURIAL COMPETENCIES
}

\author{
JuLIJA MeLniKova ${ }^{1}$ \\ Klaipèda University (Lithuania) \\ JEL̨ENA ZAŠČERINSKA ${ }^{2}$
}

Centre for Education and Innovation Research (Riga, Latvia)

\begin{abstract}
The purpose of this article is to highlight the aspects of integration of entrepreneurship into higher education (Educational sciences) in Lithuania and Latvia. The article maintains that proper entrepreneurial competencies are required to successfully start, operate and ensure the new business in the marketplace. From an educational perspective, scholars are primarily concerned with the development of individual-level competencies for entrepreneurship. Therefore the following question arises: what competencies for entrepreneurship should individuals be able to manifest when facing an entrepreneurial venture? More specifically, from educational and higher education perspectives, the question is: what competencies for entrepreneurship should universities address in their curricula for graduate programmes specifically in Educational sciences. Models of students' entrepreneurial competencies are highlighted theoretically and some empirical insights on which competencies students in Educational sciences from Lithuanian and Latvian universities would like to have acquired are provided. The article presupposes that competence-based education can be designed to promote entrepreneurial activity among university students.
\end{abstract}

Key words: entrepreneurship, higher education, Educational sciences.

JEL CODES: L 26, I 23

\section{Introduction}

Nowadays entrepreneurship is considered to be the effective strategy for development and growth of societies since it leads to technical and innovative changes and causes economic growth as well as converts the new knowledge to modern products and services. That is very important for Lithuania and Latvia, who are currently moving towards innovation driven society model. According to Lisbon strategy for growth and

1 Julija Melnikova - doctor, Klaipeda University, Faculty of Humanities and Educational Sciences, Department of Pedagogy. S. Nėries, str. 5, LT-92227 Klaipèda, Lithuania. Field of scientific interest: education management

E-mail: julijamelnikova@yahoo.com

Phone: +370 46398 616; Fax: +370 46398602

2 Paed. Jel̦ena Zaščerinska - doctor, Centre for Education and Innovation Research. Kurzemes prospekts 114-102, LV-1069 Riga, Latvia. Field of scientific interest: interdisciplinary approach to adults' education

E-mail: ceir2012@gmail.com

Phone: +37129435142 
employment, the important role of higher education in promoting entrepreneurial skills is now widely recognised. The article is based on the working definition provided by Gibb et al.: "Entrepreneurship in higher education is designed to empower staff and students to demonstrate enterprise, innovation and creativity in research, teaching and studying as well as pursuit use of knowledge across boundaries" (2013: 94).

The idea of the integration of entrepreneurship into higher education is especially relevant for Baltic countries, which have the similar historical background, transition period and traditions in higher education, and are currently seeking to re-arrange their educational systems. Moreover, the process of rapid economic convergence of European Union countries forces the higher education in Baltic countries to be competitive not only on local market but on international market as well. That means that universities in Lithuania and Latvia have to re-think their models of the preparation of the graduates, as well as of organising the study process and research work. The tendency stressed by comparative research data (Entrepreneurship in Latvia and other Baltic Countries, 2013; Entrepreneurship in Education in Baltic Sea Region, 2015) is that Lithuania and Latvia's universities and higher education system on the whole should take steps toward changing their classic role, which was merely producing knowledge towards entrepreneurship universities, which produce knowledge and create ideas and also transfer them to action in alignment with process of local, regional and international economic development.

However, it is pointed that Lithuania still lacks a clear strategy of entrepreneurship integration into higher education. The same problem has been identified in Latvia's higher education system (Entrepreneurship within Non-business studies, 2010). The context analysis of Baltic countries' higher education systems shows that the overall situation with the spread of entrepreneurship in higher education is generally very weak. The overall teaching of entrepreneurship in higher education is quite poor, especially within non-business and non-economic courses. In Lithuania noteworthy entrepreneurship teaching examples can be found, however higher education curricula even in business studies often lack coaching on how to start one's own business and acquire relevant skills. In Latvia entrepreneurship courses are missing in non-economic fields of study, and more generally inter-disciplinary approaches are rare. The low level of entrepreneurship-related abilities, knowledge and skills in the Lithuania and Latvia's universities has prompted the idea of current research.

The current research is focused on the integration of entrepreneurship into Educational sciences and covers various aspects of the issue (Melnikova, Zascerinska, 2014; Melnikova, Zascerinska, 2015a; Melnikova, Zascerinska, 2015b). In many countries entrepreneurship in non-business studies is a very new issue. In Lithuania and Latvia Educational sciences like many other social sciences and humanities traditionally are considered as less practical and applied (Dombrovsky, 2012). Entrepreneurship subjects and creating business on them are considered less important in spite of their strong base in developing ideas. However, as recent piece of research (Melnikova, Zascerinska, 2015b) reveals, Educational sciences in Lithuania and Latvia are presently under pressure: on the one hand, Educational sciences are particularly conservative due their traditional mission; on the other - Educational sciences have to equally compete with other branches of science in the fields of academic achievements, research recognition and outcomes, skills of graduates, etc. In the context of Educational sciences the concept of social entrepreneurship has been emerged.

Gibbs et al. (2013) moves towards a broader societal model of entrepreneurship, which is especially important for Educational sciences. Social entrepreneurship can be classified in one of three ways: as for-profit organisations, which use their resources to creatively address social issues; as not-for-profit organisations, which help individuals establish their own small, for-profit businesses or, as not-for-profit ventures which create economic value to fund their own programmes or to create employment and training opportunities for their client populations. The model places emphasis on the values of entrepreneurship and developing entrepreneurial behaviours, attributes and skills encompassing concepts such as emotional intelligence, vision, holistic management and the ability to build trusting relationships. This scenario translates into a need to equip students with personal entrepreneurial competencies in order to design organisations of all kinds, public, private and NGO (non-governmental organisations) and to support effective entrepreneurial behaviour. Therefore the new challenge for entrepreneurship education is that it needs to address a number of personal, 
organisational and societal competencies. This in turns challenges educators to develop modes of teaching and learning that support the development of these competencies.

The article is sought to answer the specific question: what competencies for entrepreneurship should universities address in their curricula for graduate study programmes in Educational sciences. The aim of the present study is to highlight the entrepreneurial competencies that should be acquired by graduates in Educational sciences. The specific objectives of the article are: 1) to disclose the concepts of entrepreneurship and social entrepreneurship with respect to Educational sciences; 2) to highlight theoretically the models of entrepreneurial competencies; 3 ) to disclose empirically the entrepreneurial competencies that students in Educational sciences from Lithuanian and Latvian universities would like to acquire during the study process. The methods used in the article are: analysis of scientific literature, analysis of empiric study data.

\section{The concept of entrepreneurship and social entrepreneurship with respect} to Educational sciences

The concept of entrepreneurship has a long history in the business sector. A major theme has been the creation of value through innovation (Drucker, 1999). As applied to social concerns, the concept has taken on a variety of meanings. Alvord et al. (2015) summarize the definitions of social entrepreneurship:

- Some scholars have focused on social entrepreneurship as combining commercial enterprises with social impacts. In this perspective, entrepreneurs have used business skills and knowledge to create enterprises that accomplish social purposes, in addition to being commercially viable (Emerson, Twerksy, 1996). Not-for-profit organizations may create commercial subsidiaries and use them to generate employment or revenue that serves their social purposes; for-profit organizations may donate some of their profits or organize their activities to social goals. These initiatives use resources generated from successful activities to advance and sustain social activities.

- Others have emphasized social entrepreneurship as innovating for social impact. They focus on innovations and social arrangements that have consequences for social problems, often with relatively little attention to economic viability by ordinary business criteria (Dees, 1998). Social entrepreneurs are focused on social problems. They create innovative initiatives, build new social arrangements, and mobilize resources in response to those problems rather than market criteria.

- Still others see social entrepreneurship as a way to catalyze social transformations well beyond solutions to the initial problems. From this perspective, social entrepreneurship can produce small changes in the short term that reverberate through existing systems to catalyze large changes in the longer term (Ashoka Innovators, 2000). Social entrepreneurs in this tradition need to understand not only immediate problems but also the larger social system and its interdependencies, so they can introduce new paradigms at critical leverage points that lead to cascades of mutually reinforcing changes in social arrangements. Sustainable social transformations include the innovations for social impacts and the concern for mobilizing resources that characterize the first two perspectives - and they lead to shifts in the societal context within which the original problem is embedded and sustained.

Regardless of the legal structure adopted, social enterprises operate within complex multi-agency environments that require them to adopt an open and porous approach to that environment. Social enterprises can be characterised by their desire to develop long-term relationships primarily with their client groups and other stakeholders in their environment (Leadbeater, 1997). Their enterprise orientation distinguishes them from post-hoc benefaction activities associated with charitable donations and sponsorship of community events. This also distinguishes social enterprises from other social economy organisations. Rather than relying on charitable donations, social enterprises seek to use trading activities to achieve social goals and financial self-sufficiency. While this suggests that social enterprises may have much in common with profitorientated small enterprises, their commitment to achieving specific social aims and their adoption of "social ownership" structures implies that the process of entrepreneurship may be motivated by different factors 
and organized in structures which challenge and question the position, ownership and authority of a lead entrepreneur (Carter, Shaw, 2007).

Social entrepreneurs tend to be further integrated in local settings as well. Peredo, Chrisman (2006) emphasize their embeddedness in the existing social structure of community-based enterprises, which are familiar forms of social enterprises in the developing world. Alvord et al. (2015) add that embeddedness extends to social enterprises in the developed world. As such, the role of social entrepreneurs as change agents is enhanced. Rogers (1995: 275-276) mentions the 'innovation - needs paradox,' in which those who stand to benefit the most from a new idea - like those encountering social problems - are generally laggards in adopting an innovation.

Researchers have also sought to define the social entrepreneur. Unsurprisingly, there is no universally accepted definition of what constitutes a social entrepreneur. Social entrepreneurs have been variously described as, "those people who bring to social problems the same enterprise and imagination that business entrepreneurs bring to wealth creation" (Peredo, Chrismas, 2006); individuals who initiate social innovation and change (Leadbeater, 1997); and individuals who are motivated by the opportunity to adopt an innovative approach and creative use of resources and contacts to satisfy needs which the state welfare system cannot or will not meet (Rogers, 1995).

In the present study the broader view of social entrepreneurship is accepted, which acknowledges that social entrepreneurs may combine a social purpose with a for-profit organizational structure (Dees, 1998). Creating blended value propositions (economic + social), whether in for-profit or not-for-profit firms, is a challenge that requires distinct visionary capabilities. Like traditional entrepreneurs who are innovative, opportunity oriented, resourceful, and able to create value and foster change, social entrepreneurs have a mission to make the world a better place. Accordingly, social entrepreneurs measure success not by monetary gain but by the added social value they create (Alvord, 2015).

\section{The models of entrepreneurial competencies}

In the domain of entrepreneurship, previous research has studied models of competencies that are required for initiating and managing of new business. Onstenk (2003) maintains that proper entrepreneurial competencies are required to successfully start, operate and ensure the new business in the marketplace. From an educational perspective, scholars are primarily concerned with the development of individual-level competencies for entrepreneurship (Bird, 2002). So, the following question arises: what competencies for entrepreneurship should individuals be able to manifest when facing an entrepreneurial venture? More specifically, from educational and higher education perspectives, the question is: what competencies for entrepreneurship should universities address in their curricula for undergraduate and graduate programmes. Competence - based education can be designed to promote entrepreneurial activity among university students.

Previous research has focused on identifying areas of entrepreneurship competence that have to be developed through entrepreneurship education. Suggested two main areas:

- Enterprise launching competencies;

- Enterprise managing competencies.

Ronstad (2005) suggested a set of fourteen skills to be developed. Some of these skills included creativity, ambiguity, tolerance, opportunity identification and venture evaluation, career assessment, networking, etc. Bird (2002) distinguishes the following competencies required by entrepreneur: initiative, systematic planning, creativity and innovation, risk taking and risk management, problem solving, persistence, quality performance, information management, persuation and influencing abilities. He points that entrepreneurs, who have networking and team building skills are more successful than entrepreneurs, who do not possess these skills. Hood, Young (1993) maintain that four primary areas must be developed for entrepreneurial success. These areas focus on content, skills, mentality and personality. By asking 100 leading entrepreneurs they found that content areas are those mainly addressed on business education, such as finance, marketing 
etc. The most important skills are leadership, human relations. Mentality factors include creativity, ambiguity, and vision. Personality traits refer to ability to work hard, be self-confident and responsible.

Man et al. (2002) identified a set of entrepreneurial competencies that includes opportunity, relationship, conceptual, organizing, strategic, and commitment competencies. The opportunity competencies are related to identifying, assessing and seeking market opportunities. The relationship competencies embrace the ability to build, keep and use networks with stakeholders. The conceptual competencies refer to creative thinking, innovative behaviour, assessment of risk etc. The organizing competencies are related to managerial functions such as planning, organizing, leading and controlling. The strategic competencies deal with setting, evaluating, and implementing strategies of a venture. The commitment competencies are the abilities that drive the entrepreneur to work hard and face the difficulties involved in sustaining the business.

Researchers and other stakeholders, including community and economic development agencies and politicians, have sought to identify characteristics common to social entrepreneurs (Leadbeater, 1997). Ashoka (2000) densifies social entrepreneurs and provides them with capital to launch their initiatives by identifying the "ethical" purpose of social entrepreneurs as their distinguishing feature. Ashoka proposes that social entrepreneurs are entrepreneurial, creative and agenda-setting.

Considered alongside entrepreneurship research that has sought to classify, define and characterise business or for-profit entrepreneurs (Chell et al., 1991), the characteristics suggested by Ashoka imply similarities between social and business entrepreneurs. This view is supported by Community Action Network (2001), which argues that social entrepreneurs are the equivalent of business entrepreneurs in many ways. Leadbeater (1997) concur, arguing that many traits and behaviors of social entrepreneurs mirror those of entrepreneurs working exclusively for profit objectives, including their drive, determination, ambition, charisma, leadership, the ability to communicate vision and inspire others and their maximum use of scarce resources.

\section{Students' opinion on entrepreneurial competencies in Educational sciences} in Lithuania and Latvia

The present empirical study involved 32 students (Educational sciences, Education Management) from two universities in Lithuania $(\mathrm{N}=14)$ and Latvia $(\mathrm{N}=18)$. Students' cultural and educational experience emphasized the significance of each student's opinion on research question (Luka, Ludborza, Maslo, 2009) within the present empirical study. It should be noted that opinion is determined as individual's view based on awareness and attitudes (Lūka, 2007: 104). The group of research participants (field of study and work, etc.) was considered to be homogeneous.

The empiric study guiding question is as follows: what is Lithuanian and Latvian students' opinion on teaching of entrepreneurship in Educational sciences? The exploratory type of the comparative study (Phillips, 2006) was applied within the present empirical study. The exploratory type of the comparative study aims to generate new hypotheses and questions. The exploratory methodology proceeds (Phillips, 2006): 'conceptualisation' in Phase 1, detailed description of educational phenomena in the countries to be investigated features in Phase 2, the data collection in Phase 3, explanation through the development of hypotheses in Phase 4, re-consideration of the initial questions and application of the findings to other situations in Phase 5.

The method of data collection was group discussion. Group discussion is identified as a critical conversation about a particular topic, or perhaps a range of topics, conducted in a group of a size that allows participation by all members (Rabinowitz, 2015). When the group numbers eight or more, a leader or facilitator, whether formal or informal, is almost always helpful in ensuring an effective discussion. A group discussion may not have a specific goal - many group discussions are just that: a group kicking around ideas on a particular topic (Rabinowitz, 2015).

The group discussion questionnaire included the following key questions:

How do you understand the concept of entrepreneurship?

How do you understand the concept of social entrepreneurship with regards to the field of education? 
What entrepreneurial competences would be important for graduates in Educational sciences in order to start their ventures?

The interpretive paradigm was used in the empirical study. The interpretive paradigm aims to understand other cultures, from the inside through the use of ethnographic methods such as informal interviewing and participant observation, and establishment of ethically sound relationships (Henry at al., 2003). The interpretative paradigm creates an environment for the development of any individual and helps them to develop their potential (Lūka, 2008: 52). The core of this paradigm is human experience, people's mutual everyday interaction that tends to understand the subjectivity of human experience (Lūka, 2007: 104). The paradigm is aimed at understanding people's activity, how a certain activity is exposed in a certain environment, time, conditions, i.e., how it is exposed in a certain socio-cultural context (Lūka, 2007: 104). Thus, the interpretative paradigm is oriented towards one's conscious activity, and it is future-oriented. Interpretative paradigm is characterized by the researcher's practical interest in the research question. The researcher is the interpreter.

After the answers were received the content analysis has been carried out. Informants' answers of a similar meaning were combined to so called categories. In other words, similar opinions were joined under generalized label. After qualitative research procedure there appeared possibility to calculate the frequencies of categories that show the distribution of separate opinions in the objective population. Such a calculation empowered to find out dominating and uncommon opinions.

Having generalized informants' answers the following tendencies were disclosed (see table 1).

Both Lithuanian and Latvian students understand the concept of entrepreneurship, its importance in nowadays world. The study participants emphasized that entrepreneurship is first of all about starting new venture and developing personal business. Entrepreneurship, according to the informants' mind, is needed for career goals and changes in career path. The Lithuanian and Latvian students pointed that entrepreneurship is related to financial income and profit.

Both Lithuanian and Latvian students would like to get more information about entrepreneurship in the field of education and social entrepreneurship in general. Nevertheless, informants stressed that in the field of education there are a lot of opportunities to start own venture. However, the study participants stressed that they lack knowledge on how to establish organisation (for profit or non-profit and what is the difference between them), how to manage its activity. Therefore the respondents wished to have consultations with business development experts on the issues of establishment of organisation, budget management, administration etc. Moreover, the students expressed the demand for project management competences.

The competencies listed by the study participants were structured according to Man et al. (2002) provided classification of entrepreneurial competencies.

The study participants both from Lithuania and Latvia gave the priority to Strategic competency. According to informants, vision setting skill is vital for entrepreneurs, who are going to start their own venture. Vision helps to start business and motivates to set specific goals.

The study participants from Lithuania gave the second place to Conceptual competency. Students pointed that self-efficacy as a person's belief in their own ability and task-specific self-confidence is of a major importance for future entrepreneurs that will help them to set more difficult goals, take negative feedback more positively etc. According to the study participants, entrepreneurs should possess strong initiative, be motivated and ambitious. While the Latvian participants mentioned Commitment competency. To their mind, entrepreneurs must have strong motivation to compete with others and make an impact and provide support.

According to the students from Lithuania Organizing competency is third in a list of most important entrepreneurial competencies. Students emphasized that organizing competences are the core competencies for entrepreneurs. These are the abilities to plan and manage business, to solve problems and take decisions, to control, assess the results and provide feedback on them as well as to manage the budget and resources. Successful entrepreneurs can work methodically and effectively allocate time and resources. Successful entrepreneurs are knowledgeable in assessing financing needs, determining risks, and identifying sources of capital. They are competent at accounting and money management, managing cash flows and preparing estimated and projected balance sheets. Research participants from Latvia gave priority to Conceptual com- 
petency. These entrepreneurs are often very confident in their capabilities to perform well and enjoy seeking out new opportunities. Ambitious entrepreneurs are motivated, persistent, and persevere even in the face of difficult challenges. These entrepreneurs are patient and persistent, passionate and driven. They embrace new challenges while striving to exceed set expectations and standards.

Table 1. Group discussion results

\begin{tabular}{|c|c|c|}
\hline Question & Lithuania & Latvia \\
\hline $\begin{array}{l}\text { 1. How do you under- } \\
\text { stand the concept of en- } \\
\text { trepreneurship? }\end{array}$ & $\begin{array}{l}\text { Capacity to start own business (12) } \\
\text { Earning money and making profit of any } \\
\text { activity (11) } \\
\text { Career challenges (8) } \\
\text { Ability to manage a new venture (8) } \\
\text { Personal competitiveness on the labour } \\
\text { market (5) } \\
\text { Creating personal financing security (5) }\end{array}$ & $\begin{array}{l}\text { Capacity to start own business (18) } \\
\text { Capacity to generate ideas for new ventures (16) } \\
\text { Capacity to make profit (16) } \\
\text { Ability to respond to change (10) } \\
\text { Capacity to make personal career changes (7) }\end{array}$ \\
\hline $\begin{array}{l}\text { 2. How do you under- } \\
\text { stand entrepreneurship } \\
\text { in the field of education } \\
\text { (social entrepreneur- } \\
\text { ship)? }\end{array}$ & $\begin{array}{l}\text { Starting new venture (non-profit) (14) } \\
\text { Managing social enterprises (12) } \\
\text { Tackling some social issue (7) } \\
\text { Advance in career (6) } \\
\text { Project-based activity (6) }\end{array}$ & $\begin{array}{l}\text { Starting new venture (for profit or non-profit) (18) } \\
\text { Project activity (17) } \\
\text { Providing services for community (12) } \\
\text { Recognition of social problems and tackling them } \\
(11)\end{array}$ \\
\hline $\begin{array}{l}\text { 3. What entrepreneurial } \\
\text { competences would be } \\
\text { important for graduates } \\
\text { in Educational sciences } \\
\text { in order to start their } \\
\text { ventures? }\end{array}$ & \begin{tabular}{|l} 
Strategic competency $(13)$ : \\
- $\quad$ Vision setting \\
Conceptual competency (10): \\
- Self-efficacy \\
- Strong initiative \\
- Ambition \\
Organizing competency(10): \\
- Planning and organizing \\
- Problem solving and decision \\
- making \\
- Pxamining and assessing \\
- Financial management \\
Commitment competency (8): \\
- Ability to work hard \\
- Willingness to take risks \\
Opportunity competency (8): \\
- Marketing \\
- Establishing client-customer \\
Relationship competency (7): \\
- Networking \\
- Ability to initiate collaborations \\
Ability to negotiate with com- \\
petitors
\end{tabular} & \begin{tabular}{|l} 
Strategic competency (18): \\
- $\quad$ Develop vision and strategy, plan ahead, \\
set goals and standards, sell ideas \\
Commitment competency (17): \\
- $\quad$ Strong motivation to compete \\
Conceptual competency (15): \\
- Address complex situations \\
- $\quad$ Decision making \\
Opility to be analytical, weight risks \\
- Ability to capture opportunity \\
- Ability to identify and satisfy client's \\
Reeds \\
- Good interpersonal and communicational \\
- skills \\
Ability to influence others \\
Obility to work with various stakeholders \\
- Ability to direct, lead, delegate, motivate, \\
plan and schedule work, develop program, \\
prepare budget \\
Ability to lead, coordinate, control, moni- \\
tor, and organize internal and external re- \\
sources of the business such as finance and \\
human resources
\end{tabular} \\
\hline
\end{tabular}

Commitment competency was emphasized by the Lithuanian students at the fourth place. Successful entrepreneurs are competent in both executing strategies that promote their products and establishing client / customer relationships. Successful entrepreneurs are well versed in risk management and can take into account legal considerations. They manage uncertainty by mitigating rates, protecting intellectual property, and determining liabilities. They stay apprised of business laws and regulations, and determine ways to protect themselves against loss. Latvian students distinguished Opportunity competency, which relates to the ability to recognize opportunity, ability to capture opportunity, ability to identify customers' needs. 
Lithuanian students named some skills that belong to Opportunity competency. In their opinion, entrepreneurs need skills to analize market tendencies, offers and demands, focus on clients' needs and satisfy them. Both Lithuanian and Latvian respondents mentioned Relationship competency. To their mind, entrepreneurs with strong networking skills are perceived as trustworthy, can negotiate with competitors, establish business connections with partners, and identify mutual goals. Latvian students named Organizing competency as well. To be successful, entrepreneurs must understand the basic principles of business.

Research participants demonstrated high interested in the issue of entrepreneurship. Both Lithuanian and Latvian students expressed a certain need for more information about entrepreneurship in general and social entrepreneurship in particular. Informants stressed that they would like to learn more about the opportunities to start own ventures (no matter for-profit or non-profit) in the field of education. Therefore during the study process they would like to acquire competencies that are important for starting their own business. The most valuable important competencies - Strategic, Conceptual, Commitment competencies, etc., - were mentioned as in Lithuania as in Latvia.

\section{Conclusions}

From an educational perspective, scholars are primarily concerned with the development of individual-level competencies for entrepreneurship. The following research question from educational and higher education perspectives has been formulated: what competencies for entrepreneurship should universities address in their curricula for graduate programmes specifically in Educational sciences. Competence - based education can be designed to promote entrepreneurial activity among university students.

Entrepreneurship is understood as creation of value through innovation. Social entrepreneurship which is classified in three ways: as for-profit organisations, which use their resources to creatively address social issues; as not-for-profit organisations, which help individuals establish their own small, for-profit businesses or, as not-for-profit ventures which create economic value to fund their own programmes or to create employment and training opportunities for their client populations. The article suggests that social enterprises may have much in common with profit-orientated small enterprises and both traditional entrepreneurs and social entrepreneurs require a distinct set of competencies to successfully start, operate and ensure the new business.

On the basis of previous research the models of entrepreneurship competencies are highlighted. The empiric study has been based on a classification provided by Man et al. (2002) identifying a set of entrepreneurial competencies that includes opportunity, relationship, conceptual, organizing, strategic, and commitment competencies. Empiric study participants demonstrated high interested in the issue of entrepreneurship. Both Lithuanian and Latvian students expressed a certain need for more information about entrepreneurship in general and social entrepreneurship in particular. Informants stressed that they would like to learn more about the opportunities to start own ventures (no matter for-profit or non-profit) in the field of education. Therefore during the study process they would like to acquire competencies that are important for starting their own business. The most valuable important competencies - Strategic, Conceptual, Commitment competencies, etc., - were mentioned as in Lithuania as in Latvia.

The present research has limitations. The inter-connections between entrepreneurship, social entrepreneurship, Educational sciences and Baltic countries have been set. However the further research on the relevance of entrepreneurship in higher education, specifically Educational sciences, is needed. Another limitation is the empirical study conducted by involving the students of two higher education institutions only. Therein, the results of the study cannot be representative for the whole area. Nevertheless, the results of the research - elements of entrepreneurship competence - may be used as a basis of analysis of integration of entrepreneurship in Educational sciences within higher education. If the results of other institutions had been available for analysis, different results could have been attained. There is a possibility to continue the study.

Further research tends to focus on empirical studies to compare students' and educators' opinions on teaching of entrepreneurship in Educational sciences within higher education. The search for relevant methods 
for evaluation of students' and educators' opinions on teaching of entrepreneurship in Educational sciences within higher education is proposed. And a comparative research of other countries could be carried out, too.

\section{References}

Alvord, S. H. (2015). Social Entrepreneurship and Societal Transformation: An Exploratory Study. The Journal of Applied Behavioral Science. Retrieved 28/11/2015 from http://jab.sagepub.com/content/40/3/260.full.pdf + html

Ashoka Innovators for the Public. (2000). Selecting leading social entrepreneurs. Washington, DC: Author.

Bird, B. (2002). Learning entrepreneurship competencies: the self-directed learning approach. International Journal of Entrepreneurship Education, Vol. 1, p. 203-227.

Carter, E., Shaw, C. (2007). Social entrepreneurship: Theoretical antecedents and empirical analysis of entrepreneurial processes and outcomes. Journal of Small Business and Enterprise Development, Vol. 14 (3), p. 418-434.

Chell, E., Hawthorne, J., Brearley, S. (1991). The Entrepreneurial Personality: Concepts. Casesand Categories. London: Routledge.

Dees, J. G. (1998). Enterprising nonprofits: What do you do when traditional sources of funding fall short? Harvard Business Review, Vol. 76 (1), p. 55-67.

Dombrovsky, V., Ubele, I. (2005). Entrepreneurship in Latvia. Telia Sonera Institute Discussion Paper, No. 2, p. 6-32. Stockholm School of Economics in Riga, Latvia.

Drucker, P. (1999). Innovation and Entrepreneurship. Butterworth-Heinemann, Oxford.

Emerson, J., Twerksy, F. (Eds.). (1996). Newsocial entrepreneurs: The success, challenge and lessons of non-profit enterprise creation. San Francisco: Roberts Foundation, Homeless Economic Development Fund.

Entrepreneurship in Education in Baltic Sea Region. (2015). Retrieved 28/11/2015 from http://socialinnovation.lv/en/ educational-materials-of-social-entrepreneurship-development-in-the-baltic-sea-region/

Entrepreneurship in higher education, especially within non-business studies (Final report of expert group). (2015). Retrieved 28/11/2015 from http://www.koda.ee/public/entr_highed.pdf

Entrepreneurship in Latvia and Other Baltic States: Results from the Global Entrepreneurship Monitor. (2013). Retrieved 28/11/2015 from http://freepolicybriefs.org/2013/11/04/entrepreneurship-in-latvia-and-other-balticstates-results-from-the-global-entrepreneurship-monitor/

Gibb, A., Haskins, G., Robertson, I. (2013). Leading the entrepreneurial university: Meeting the entrepreneurial development needs of higher education institutions. Universities in Change, p. 9-45. New York: Springer.

Henry, C., Hill, F., Leitch, C. (2003). Entrepreneurship Education and Training. Ashgate, Aldershot.

Hood, J. N., Young, J. E. (1993). Entrepreneurship's requisite areas of development: a survey of top executives in successful entrepreneurial firms. Journal of Business Venturing, Vol. 8, p. 115-135. Retrieved from: http://dx.doi. org/10.1108/14626000710773529

Izquierdo, E., Salazar, D. (2005). The importance of competencies for Entrepreneurship: a view from entrepreneurs and scholars' perspective. Retrieved from: http://www.espae.espol.edu.ec/images/documentos/publicaciones/documentos_trabajo/entrepreneurship/Importance.pdf

Leadbeater, C. (1997). The Rise of the Social Entrepreneur. Demos, London.

Luka, I. (2007). Students and the educator's co-operation as a means of development of students' ESP competence. Paper presented at the European Conference on Educational Research, University of Goteborg, 10-12 September 2008. The document was added to the Education-line collection on 18 July 2008. British Education Index data base. ID 172916. Retrieved from: http://www.leeds.ac.uk/educol/documents/172916.htm

Luka, I., Ludborza, S., Maslo, I. (2009). Effectiveness of the use of more than two languages and quality assurance in European interuniversity master studies. Paper presented at the European Conference on Educational Research, University of Vienna, September 28-30.

Man, T. W. Y., Lau, T., Chan, K. F. (2002). The competitiveness of small and medium enterprises: a conceptualization with focus on entrepreneurial competencies. Journal of Business Venturing, Vol. 17, p. 123-142.

Melnikova, J., Zaščerinska, J. (2015a). Entrepreneurship in Education Sciences in the Baltic Countries: Mezzo-Level Context Analysis. Proceedings of the $17^{\text {th }}$ Student and Teacher Scientific and Practical Conference National Economy Development: Problems and Solutions, 28 May, 2015, p. 22-26. Rēzekne, Latvia: Rēzeknes Augstskolas Izdevniecība 2015.

Melnikova, J., Zascerinska, J. (2015b). Entrepreneurship education in teacher training. ATEE Spring University "Changing Education in a Changing Society", Vol. 2, p. 5-15.

Melnikova, J., Zascerinska, J., Glonina, O. (2014). A conceptual framework on entrepreneurship education in teacher training. Rīgas Pedagog̣ijas un izglîtības vadības akadēmijas X Starptautiskās Jauno zinātnieku konferences rakstu krājums. Rīga: Rīgas Pedagoǵijas un izglìitības vadības akadēmija, p. 60. 
Onstenk, J. (2003). Entrepreneurship and vocational education. European Educational Research Journal, Vol. 2, p. 7489 .

Peredo, A., Chrisman, J. (2006). 'Towards a theory of community-based enterprise'. Academy of Management Review, Vol. 31, p. 309-328.

Rogers, E. (1995). Diffusion of Innovations. 4th edn. New York, Free Press.

Ronstad, R. (2005). The Educated Entrepreneurs: a new era of entrepreneurial education is beginning. American Journal of Small Business, Vol. 10, p. 7-23.

Yujuico, E. (2008). Opportunity Recognition in Social Entrepreneurship: A Thematic Meta Analysis. Journal of Entrepreneurship, Vol. 21 (1), p. 25-58. Retrieved 20151128 from http://ser.oxfordjournals.org/content/6/3/493. abstract

\title{
VERSLUMO INTEGRAVIMAS I AUKŠTĄJI MOKSLĄ (UGDYMO MOKSLUS) LIETUVOJE IR LATVIJOJE: STUDENTU VERSLUMO KOMPETENCIJŲ ASPEKTAS
}

\author{
JuliJa Melnikova, Jeļena ZašČERINSKa \\ (Klaipedos universitetas, Lietuva; Edukologijos ir inovacijų tyrimo centras, Latvija)
}

\section{Santrauka}

Verslumo aukštajame moksle skatinimas būtinas siekiant optimizuoti aukštaji mokslą ir parengti specialistus, kurie ne tik gebètų įsisąmoninti žinias, bet ir kurti inovacijas. Verslumo integravimas ị aukštaji mokslą - aktuali problema Baltijos šalims, siekiančioms pakeisti tradicinius aukštojo mokslo organizavimo modelius ị darbo rinkos poreikius orientuotus modelius. I̦vairūs statistiniai duomenys ir pranešimai išryškina verslumo aukštajame moksle poreikị, tačiau bendra strategija ir aukštojo mokslo verslumo skatinimo politika nesukurta. Naujausios strategijos skatina aukštojo mokslo ịstaigas ịtraukti verslumo ugdymo dalykus ị visų sričių studijas. Dėmesys straipsnyje sutelktas ties verslumo integravimu ị Ugdymo mokslų sritị ir analizuoja studentų verslumo kompetencijų aspektą. Atlikti tyrimai verslumo ịtakos analizès pagrindu iškelia studentų verslumo kompetencijų ugdymo(si) poreikį, kuris tiesiogiai veikia asmenybès formavimąsi, darbo rinką, skatina novatoriško verslo steigimą, taigi didina jaunų žmonių vaidmenį visuomenejje ir ekonomikoje. Todèl straipsnyje keliamas klausimas, kokios verslumo kompetencijos turètų būti integruotos ị ugdymo mokslų studijų programų turinị.

Teorinèje straipsnio dalyje aptariamos verslumo ir socialinio verslumo sampratos, apžvelgiami verslumo kompetencijų modeliai. Teigiama, kad verslumo ir socialinio verslumo srityje būtinos kompetencijos iš esmès nesiskiria. Empiriniam tyrimui pasirinkta T. Man ir kt. (2002) verslumo kompetencijų klasifikacija, kurią sudaro 6 raktinès kompetencijos. Empirinis tyrimas konstruojamas kaip lyginamoji studija, kurios tikslas - išsiaiškinti Lietuvos ir Latvijos studentų nuomonę apie verslumo kompetencijų ugdymą(si) ugdymo mokslų srityje. Taikyti kokybinio tyrimo metodai: grupinė diskusija, kaip tyrimo duomenų rinkimo metodas, kokybinių duomenų turinio analizè, kaip duomenų analizès metodas.

Atlikus tyrimą išryškejjo, kad tiek Lietuvos, tiek Latvijos universitetų studentai suinteresuoti ugdytis verslumą. Informantai išsakè poreikị gauti daugiau informacijos apie verslumą ir socialinį verslumą, siejant tai su ugdymo kontekstu. Juos domintų galimybès steigti verslą (pelno / ne pelno siekiančias organizacijas), bet tam, jų nuomone, reikia specifinių kompetencijų, kuriuos turètų būti ugdomos dar studijuojant. Svarbiausios jų - strateginè ir konceptualioji kompetencijos - minètos tiek Lietuvos, tiek Latvijos informantų atsakymuose.

PAGRINDINIAI ŽODŽIAI: verslininkystè, aukštasis mokslas, ugdymo mokslai. 